\title{
Exercising privacy rights in medical science
}

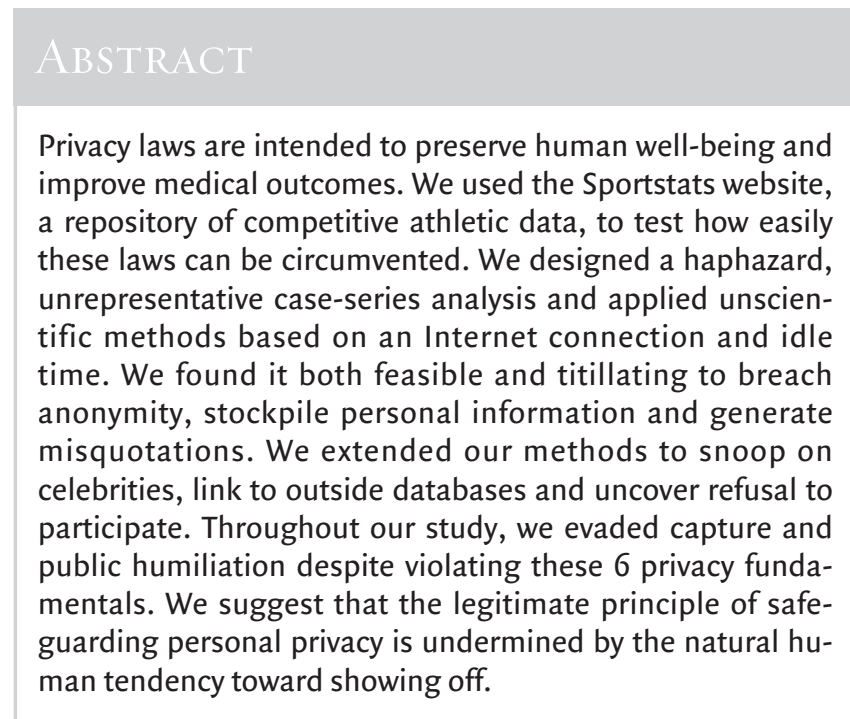

$\mathrm{W}$ e are shocked! Shocked! Shocked! We are shocked at the amount of sensitive personal information being released on thousands of Canadians, including some of our country's most prominent citizens. The widespread dispersal of and the easy access to health data offends our sensibilities as medical scientists who are respectful of Canadian privacy laws. We prefer to jump through innumerable bureaucratic hoops to obtain data for research, and we believe that our rivals in other scientific fields ought to do the same.

We uphold traditional values. We reminisce about the golden age when conducting a chart review was the standard for measuring quality of care. Ethics submissions were like sustained foreplay, and privacy impact assessments provided another thrill verging on "joy of the forbidden." The 3-week turnarounds gave us time to savour and appreciate every passing minute. And joy! Even more delays occurred when health records departments could not find the relevant charts.

Woe unto those who visit the Sportstats website (www. sportstats.ca). ${ }^{1}$ This site reveals personal data obtained from timers affixed to athletes competing in sporting events across North America. This database is thorough and is searchable for many past years. In fact, we recommend using these data if you need personal information about your neighbour, nemesis or boss. In this article, we offer pointers on 6 violations of privacy for those mavericks who flaunt the scientific establishment (not us!).

\section{Breach anonymity}

A major sin of any medical study is breaching the anonymity of the participants. In contrast, the Sportstats website can be used to fully identify individuals in all their glory. For exam-

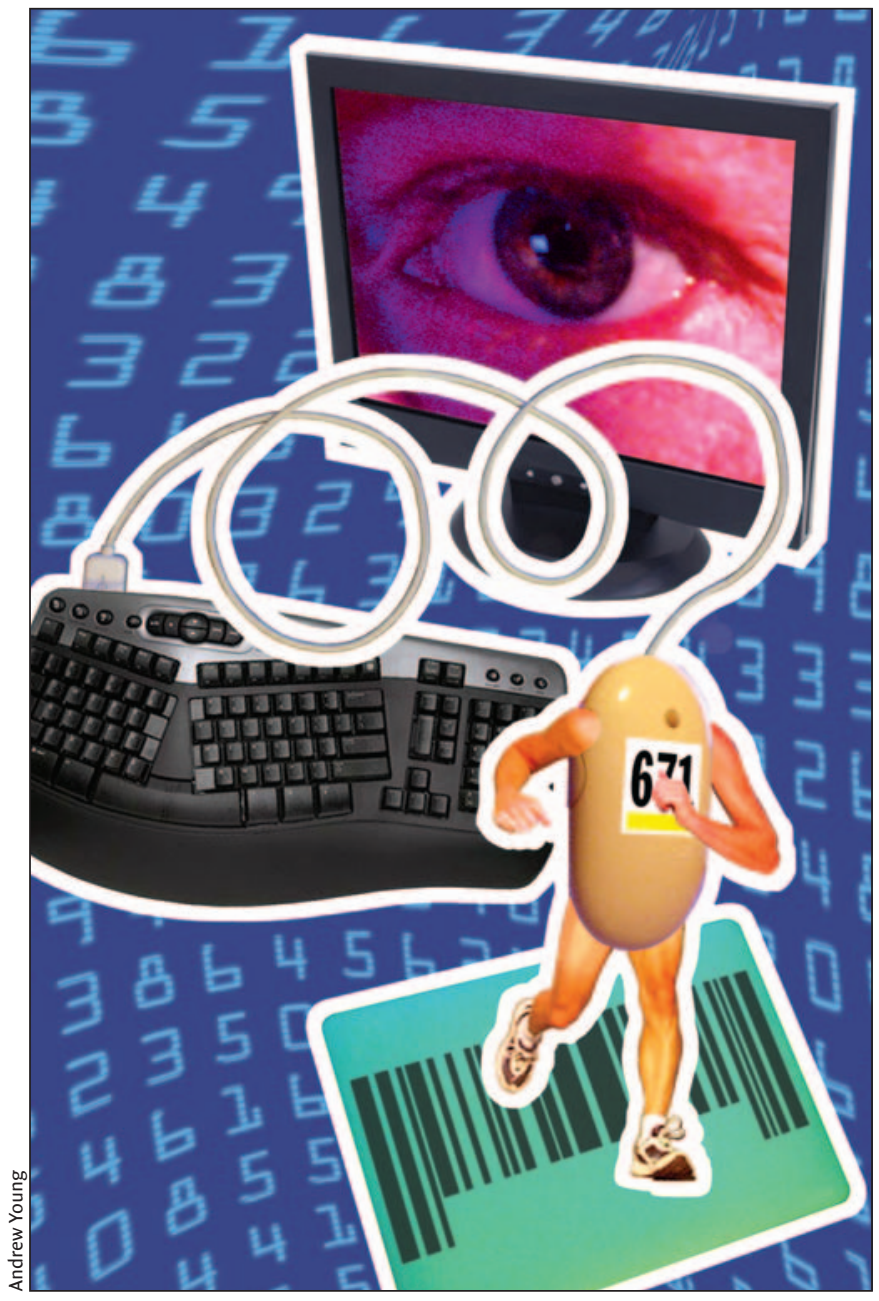

ple, you could perform a search using our names and make a head-to-head comparison of our results (Figure I). Redelmeier seems to post faster running times than Hillmer despite a handicap of IO-I5 years. Perhaps Redelmeier slacks off at work or neglects his family. Or perhaps Hillmer should ignore his Blackberry while running.

\section{Stockpile personal information}

Unbridled stockpiling of personal information is generally frowned upon, yet Sportstats excels in this regard as well. Consider André Picard, arguably the most powerful medical reporter for Canada's most powerful national newspaper. André (the database is so intimate, we'll call him by his first name without permission) has completed 22 races over the past 5 years with extremely competitive times. Could this be an indicator of his speed at work? Notice too, how André travels frequently to exotic Canadian locales, such the Toronto Zoo. 


\section{Generate misquotations}

Sportstats also offers splendid opportunities for misquotation and defamation. Consider David Miller, the mayor of Canada's largest city. Apparently, David completed the Ford Ironman Coeur d'Alene in June 2007 in I3h:46m:3is. Wow! A time that beats nearly 900 other competitors! Given the busy schedule of any politician, a scandalmonger may wonder whether David's work is aided by anabolic steroids. Also note that Subaru and Isuzu have sponsored other races in which David has participated, raising questions about all the public transit fare increase under his mayoralty.

\section{Snoop on celebrities}

Star worship is everywhere, and this database can also track celebrities. Consider David Sackett, arguably the father of modern day clinical epidemiology. David is about as close to a rock star as any clinician scientist can get in Canada (and he even bears a passing resemblance to David Crosby). According to Sportstats, it appears that David has children who spend a lot of time running quickly, as shown by the results of the annual Around the Bay Road Race, a $30-\mathrm{km}$ race held in Hamilton, Ont. Nice to know that his kids turned out better than some other celebrity kids.

\section{Link to outside databases}

The Sportstats database also permits intrusion into a person's professional life. Consider George Smitherman, the longterm Ontario minister of health. George is quite fit and ran the Toronto Mount Sinai Hospital Io-km race in 2003. Go surf other databases (e.g., Google) and find out (faster than you can say "consent is for wimps"!) that 3 years later he announced \$8 million of funding to the Mount Sinai Hospital. The link between George's performance at the Casino Niagara International Half-Marathon in 2004 and his government's permissive attitude toward gambling can't be missed either.

\section{Uncover refusal to participate}

Clinical researchers assure patients that their care won't be jeopardized if they decline to participate in a study. Sportstats, in contrast, makes no pretense at chivalry because it publicizes both active participation as well as the absence of exercise by those less aerobicly inclined. Consider performing a search for Canada's most venerated news anchor, Lloyd Robertson. This search returns no matches and implies he does not participate in running events (despite his sometimes sporty attire). Alas, another indictment of journalists as voyeurs rather than as active contributors to society.

\section{Interpretation}

These 6 violations all contradict the accepted tenets of personal privacy. In fact, Ontario's privacy regulations explicitly prohibit such uses of health data. ${ }^{2}$ We are baffled by the lack of public outcry about the breach of privacy by Sportstats. Is it possible that we are overreacting to the current privacy legislation in health care in Canada? Perhaps the message is that our research should focus more on sports medicine and less on lethal diseases.

Imagine the potential for medical research if health data were so easily obtained. Software could be integrated into

\begin{tabular}{|c|c|c|c|}
\hline \multicolumn{4}{|c|}{ Donald Redelmeier } \\
\hline $\operatorname{Sep} 1,2007$ & $\begin{array}{l}\text { The Canadian Iron Distance, } 1 / 2 \text { iron Distance, Sprint, Try a } \\
\text { Tri - Half Ironman Distance Triathlon }\end{array}$ & Don REDELMEIER & $4: 55: 22$ \\
\hline May 6,2007 & Sporting Life Toronto $10 \mathrm{~K}-10 \mathrm{~km}$ & DON REDELMEIER & $39: 37.6(39: 08.9)$ \\
\hline Jul 9, 2006 & Peterborough Triathlon \& Duathlon - 1/2 Ironman Triathlon & DON REDELMEIER & $5: 21: 48$ \\
\hline May 7,2006 & Sporting Life $10 \mathrm{~K}-10 \mathrm{~km}$ & DON REDELMEIER & $0: 40: 45.6(0: 40: 34.4)$ \\
\hline Jul 24,2005 & Ford Ironman USA Lake Placid Triathlon - Overall & DON REDELMEIER & $12: 17: 43$ \\
\hline \multicolumn{4}{|c|}{ Michael Hillmer } \\
\hline Aug 30,2003 & $\begin{array}{l}\text { Canadian Half Triathlon, Duathlon \& } 8 \mathrm{~km} \text { Run }-1 / 2 \text { Ironman } \\
\text { Triathlon }\end{array}$ & Michael Hillmer & $6: 00: 39$ \\
\hline Jul 19,2003 & Niagara Triathlon \& Duathlon - Triathlon & MICHAEL HILLMER & $1: 43: 52$ \\
\hline Jun 14,2003 & Muskoka Sprint Triathlon - Sprint Triathlon & MICHAEL HILLMER & $1: 33: 22$ \\
\hline $\operatorname{Sep} 15,2002$ & $\begin{array}{l}\text { Scotiabank Toronto Waterfrent Marathon, Half-Marathen } \$ 5 \mathrm{~km} \\
\text { - Half-Marathon }\end{array}$ & michael Hillmer & $1: 56: 29.8(1: 55: 58.4)$ \\
\hline Jun 19,1999 & $\begin{array}{l}\text { Subaru Triathlon Series - Muskoka Triathlon \& Duathlon - Long } \\
\text { Course Triathlon }\end{array}$ & 9 MICHAEL HILLMER & \\
\hline
\end{tabular}

Figure 1: Screen capture from the Sportstats website comparing recent race results for Donald Redelmeier and Michael Hillmer. 
websites so that novice users could conduct observational research and create their own regression models with receiver operating characteristic curves. This sort of unfettered access might help alleviate shortages in funding for health care research. Indeed, important clinical and policy questions could be answered as science fair projects by high school students!

We acknowledge that Sportstats is on to something, and they are not alone. Among those who also deserve praise is, of course, the Ontario government, whose "sunshine" laws publicize large salaries as an indicator of each person's financial health. ${ }^{3}$ For example, consider David Naylor who earned $\$ 374220$ as president of the University of Toronto last year. He's worth every penny. Now, if only someone could release an electronic medical record to make researchers' lives easier.

Michael Hillmer MSc

Graduate student

University of Toronto

Donald A. Redelmeier MD MS(HSR)

General internist

Toronto, Ont.

Acknowledgements: Michael Hillmer is supported by the Canadian Institutes of Health Research. Donald Redelmeier holds a Canada Research Chair in medical decision science and is supported by the Canadian Institutes of Health Research and the Physicians' Services Incorporated Foundation.

Sadly, neither author is sponsored by Gatorade, Nike or other elite sports companies (but we are happy to entertain offers!). Drafts of this manuscript were kept away from the Privacy Commission for Ontario, the privacy officer of the Institute for Clinical Evaluative Sciences, the ethics committee at Sunnybrook Health Sciences Centre and our spouses. We also failed to act on helpful comments from several other people, including Nick Daneman, Dan Hackam, David Hodgson, Jan Hux, David Juurlink, Michael Schull, Steve Shumak, Matthew Stanbrook and Jack Williams.

\section{REFERENCES}

I. Sportstats. Ottawa: Sportstats; 2007. Available: www.sportstats.ca (accessed 2007 Oct 24).

2. Information and Privacy Commissioner of Ontario. A guide to the personal health information protection act. Toronto: The Office of the Information and Privacy Commissioner of Ontario; 2004. Available: www.ipc.on.ca/images/Resources /hguide-e.pdf (accessed 2007 Oct 24).

3. Ontario Ministry of Finance. Public sector salary disclosure 2007 (disclosure for 2006). Ottawa: the Ministry; 2007. Available: www.fin.gov.on.ca/english/publications /salarydisclosure/2007/ (accessed 20007 Oct 24). 